\title{
The Impact of Altered Gravity and Vibration on Endothelial Cells During a Parabolic Flight
}

\author{
Markus Wehland ${ }^{a} \quad$ Xiao Ma ${ }^{b}$ Markus Braun ${ }^{c} \quad$ Jens Hauslage ${ }^{d} \quad$ Ruth Hemmersbach $^{d}$ \\ Johann Bauere Jirka Grosse ${ }^{f}$ Manfred Infanger ${ }^{a}$ Daniela Grimma,b
}

${ }^{a} \mathrm{Clinic}$ for Plastic, Aesthetic and Hand Surgery, Otto-von-Guericke-University Magdeburg, Magdeburg,

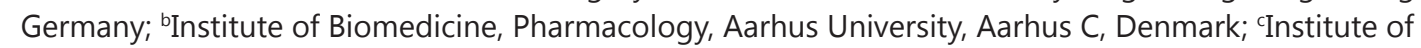
Plant Molecular Physiology and Biotechnology (IMBIO), Bonn University, Gravitational Biology Group, Bonn, Germany; Institute of Aerospace Medicine, German Aerospace Centre (DLR), Cologne, Germany; eMax Planck Institute of Biochemistry, Martinsried, Germany; 'Department of Nuclear Medicine, University of Regensburg, Regensburg, Germany

\section{Key Words}

Endothelial cells - Parabolic flight - Microgravity • Hypergravity • Vibration • Cytoskeleton • Angiogenesis $•$ Extracellular matrix $•$ Apoptosis $•$ Cell cycle

\begin{abstract}
Background: Endothelial cells (EC) cultured under altered gravity conditions show a cytoskeletal disorganization and differential gene expression (short-term effects), as well as apoptosis in adherently growing EC or formation of tubular 3D structures (long-term effects). Methods: Investigating short-term effects of real microgravity, we exposed EC to parabolic flight maneuvers and analysed them on both protein and transcriptional level. The effects of hypergravity and vibration were studied separately. Results: Pan-actin and tubulin proteins were elevated by vibration and down-regulated by hypergravity. $\beta$-Actin was reduced by vibration. Moesin protein was reduced by both vibration and hypergravity, ezrin potein was strongly elevated under vibration. Gene expression of $A C T B, C C N D 1, C D C 6, C D K N 1 A, V E G F A$, $F L K-1, E Z R, I T B G 1, O P N, C A S P 3, C A S P 8, A N X A 2$, and BIRC5 was reduced under vibration. With the exception of CCNA2, CCND1, MSN, RDX, OPN, BIRC5, and ACTB all investigated genes were downregulated by hypergravity. After one parabola (P) CCNA2, CCND1, CDC6, CDKN1A, EZR, MSN, OPN, VEGFA, CASP3, CASP8, ANXA1, ANXA2, and BIRC5 were up-, while FLK1 was downregulated. EZR, MSN, OPN, ANXA2, and BIRC5 were upregulated after 31P. Conclusions: Genes of the cytoskeleton, angiogenesis, extracellular matrix, apoptosis, and cell cycle regulation were affected by parabolic flight maneuvers. We show that the microgravity stimulus is stronger than hypergravity/vibration.




\section{Introduction}

The endothelial cells (EC) form the inner coating of blood vessels and they are key players in human cardiovascular physiology. EC can regulate blood pressure by secreting NO and are very sensitive to external stimuli upon which they may activate different mechanisms of defense [1-5].

Furthermore, when exposed to altered gravity conditions, EC showed strong reactions ranging from alterations in cytoskeletal arrangement and gene expression after only $22 \mathrm{~s}$ of real microgravity to long-term effects such as formation of defined 3D structures on the Random Positioning Machine (RPM), a device which aims to simulate microgravity on Earth by randomly rotating the sample around all three axes in space, and thereby cancels out the effect of the gravity vector over time [6-11]. Some of these 3D structures assume tubular shapes resembling vascular intimas and recent studies have shown that these structures are a promising basis toward the systematic tissue engineering of vessels $[12,13]$.

During and after spaceflights, astronauts suffer from many different health problems, including an impaired immune system, bone and muscle loss, orthostatic intolerance, and cardiovascular problems $[14,15]$. The latter are very likely caused by an endothelial dysfunction. There are several studies demonstrating the effects of both simulated and real microgravity on ECs. Cytoskeletal remodelling and actin reduction was a common observation in all the experiments and occurred on a clinostat, on a RPM and in cells cultured in a Rotating Wall Vessel (RWV) bioreactor. In addition to this, it was also found that the expression of surface adhesion molecules and extracellular matrix proteins was changed. Some of these changes resemble those observed in cardiovascular disease [16-20].

After first discovering some altered signalling pathways in ECs cultured on a RPM [10, 13], we have recently analyzed the short-term effects of real microgravity during several parabolic flight campaigns [11]. Our findings were consistent with those described above, but in contrast to the microgravity simulation techniques, there are several additional factors which might have an influence on the EC cultured on board of the aircraft. There will always be a certain amount of vibrations. In addition, there are before and after each phase of microgravity two phases of hypergravity of $1.8 \mathrm{~g}$. The influence of hypergravity on endothelial cells has been studied before, but with different g-forces $(3 \mathrm{~g})$ and different durations of exposure (10 min and $48 \mathrm{~h}$, respectively) [21, 22]. Vibrations, however, have not been intensively investigated. Several cell types, among them ECs, have been cultured on devices which transmit vibrations in the nanometer scale into the cells [23], but no effects have been found. Low-frequency fluid vibration at up to $12 \mathrm{~Hz}$ revealed an ERK1/2 mediated ET-1 release [24], but these frequencies are not comparable to those on the ZERO-G aircraft.

It is important to investigate and characterize the influence of short-term hypergravity and vibration during a parabolic flight. We therefore aimed to simulate the acceleration profile of one or 31 parabolas as well as the vibrations occurring during the whole flight. Protein as well as gene expression were analyzed and compared to the results obtained from cells exposed to a parabolic flight.

Further insights into the biological processes of ECs in Space will advance the possibilities of both the effective treatment of impaired endothelium in astronauts in Space missions as well as the refinement of tissue engineering techniques towards the generation of a functional blood vessel.

\section{Materials and Methods}

\section{Cell culture procedure}

Human endothelial EA.hy926 cells [25] were grown in RPMI 1640 medium (Invitrogen, Eggenstein, Germany) supplemented with $10 \%$ fetal bovine serum (Biochrom, Berlin, Germany), 100 units penicillin/ $\mathrm{mL}$, and $100 \mu \mathrm{g}$ streptomycin/mL. 
Fig. 1. Platforms to investigate altered gravity and vibration on human endothelial cells. Parabolic flight airplane, the Novespace A300 ZERO-G Airbus (A, Novespace). Overview of the experimental rack (B), detailed views on the MuSIC (Multi Sample Incubator Centrifuge, C) and the Vibraplex vibration platform (D). both DLR, Cologne, Germany.

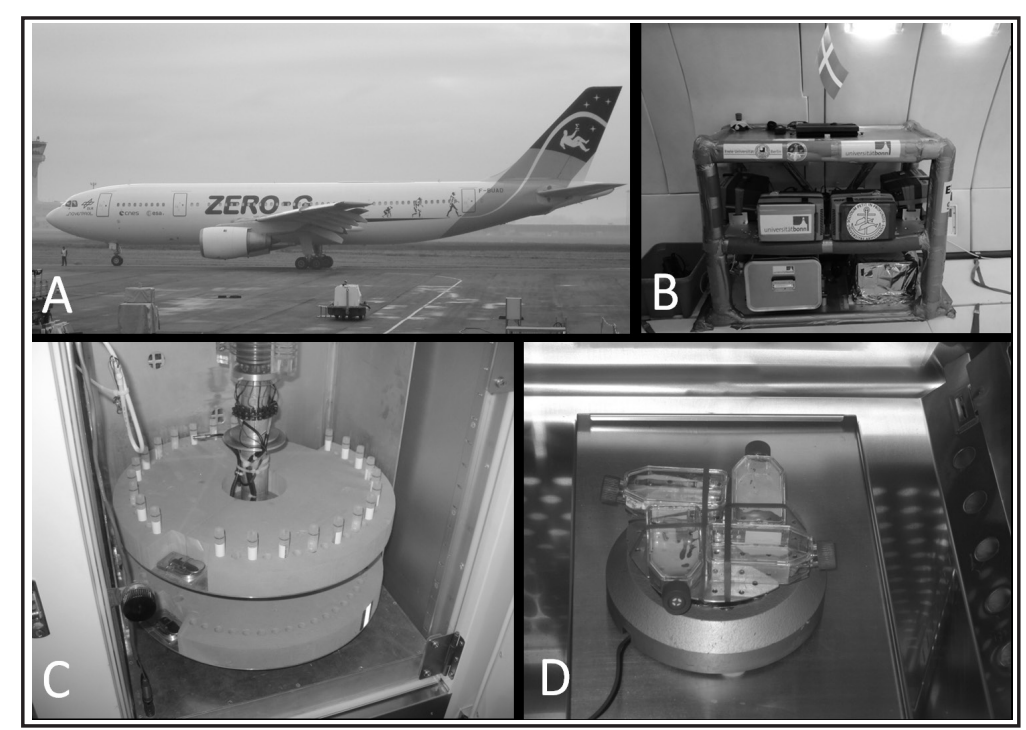

The cell culture procedure for the parabolic flight campaigns was published recently [26]. Briefly, for the flight experiments we used both T75 cell culture flasks $\left(75 \mathrm{~cm}^{2}\right.$, Sarstedt, Nümbrecht, Germany) with subconfluent layers of $10^{6}$ cells, filled with $10 \mathrm{~mL}$ of medium. Syringes containing the appropriate fixative were connected to the flasks via a flexible tube and three-way valve.

Cells for quantitative real-time PCR were fixed with RNAlater (Applied Biosystems, Darmstadt, Germany) at a ratio of $4: 1$, while samples for Western blot analysis were fixed by addition of ethanol up to a final concentration of $70 \%$.

One hour before each flight, the cell culture flasks were transported to the aircraft (Fig. 1A) in transportable Cell Trans 4016 incubators (Labotect, Göttingen, Germany) and placed into similar devices which were installed on an experimental rack (Fig. 1B) and pre-heated to $37^{\circ} \mathrm{C}$. Furthermore, in-flight $1 \mathrm{~g}$ control samples were incubated in a centrifuge which was also mounted on the rack. This centrifuge was controlled by a $g$-sensor and began operation upon reaching microgravity. In addition, corresponding static $1 \mathrm{~g}$ samples were cultured in the laboratory ( $1 \mathrm{~g}$ controls).

Cells were fixed after P1 and P31. All cell samples were transported back to the laboratory for further investigations immediately after landing of the aircraft.

Of both parabolic flight samples $(\mu g)$ and $1 \mathrm{~g}$ control groups, we collected N=6 T75 cell culture flasks for Western blot analyses (P31) and N=6 for quantitative real-time PCR (P1, P31).

\section{Parabolic flight}

All parabolic flight experiments were conducted aboard the Airbus A300 ZERO-G, which is operated by Novespace and is based in Bordeaux, France. On each of the three days of the campaign, a parabolic flight, which lasts about $3 \mathrm{~h}$, including take-off and landing and encompasses 31 parabolas, takes place. Every parabola started from a steady normal horizontal flight and typically included two hypergravity (1.8 $\mathrm{g}$ ) periods of $20 \mathrm{~s}$, separated on average by a $22 \mathrm{~s}$ microgravity period. The first test parabola was followed by six series of five parabolas, separated by breaks of 4 and $8 \mathrm{~min}$, respectively. The microgravity level achieved by parabolic flights is $0 \pm 0.05 \mathrm{~g}$. The data presented emerged from the $12^{\text {th }}, 13^{\text {th }}, 14^{\text {th }}$ and $16^{\text {th }}$ parabolic flight campaigns of the German Space Agency (DLR), representing a total of 12 parabolic flights or 372 parabolas.

\section{Hypergravity experiments}

The method was recently published in detail [26]. Hypergravity was achieved by centrifugation on a Multi Sample Incubator Centrifuge (MuSIC, DLR, Cologne, Germany) (Fig. 1C) placed in an incubator at $37{ }^{\circ} \mathrm{C}$ and $5 \% \mathrm{CO}_{2}$. Confluently growing cells from $\mathrm{T} 75$ cell culture flasks were trypsinized and transferred into 5-mL tubes. The tubes were filled up with cell culture medium and the cells were allowed to equilibrate before centrifugation. Corresponding to the fixation times of the cells on the parabolic flight, the cells were exposed to two $20 \mathrm{~s}$ long $1.8 \mathrm{~g}$ phases interrupted by a $22 \mathrm{~s}$ pause (P1) and $2 \mathrm{~h}$ lasting $1.8 \mathrm{~g}$ phases (P31). Control experiments on the Short Arm Human Centrifuge (SAHC) at the DLR with cells growing in T75 cell culture flasks showed no difference to the results from the MuSIC device (data not shown). We collected N=5 
Table 1. Primers used for quantitative realtime PCR. All sequences are given in 5'-3' direction

\begin{tabular}{|c|c|c|}
\hline Gene & Primer Name & Sequence \\
\hline \multirow[t]{2}{*}{$18 S r R N A$} & $18 S-F$ & GGAGCCTGCGGCTTAATTT \\
\hline & $18 \mathrm{~S}-\mathrm{R}$ & CAACTAAGAACGGCCATGCA \\
\hline \multirow[t]{2}{*}{$A C T B$} & ACTB-F & TGCCGACAGGATGCAGAAG \\
\hline & ACTB-R & GCCGATCCACACGGAGTACT \\
\hline \multirow[t]{2}{*}{ ANXA1 } & ANXA1-F & GCCAAAGACATAACCTCAGACACAT \\
\hline & ANXA1-R & GAATCAGCCAAGTCTTCATTCACA \\
\hline \multirow[t]{2}{*}{ ANXA2 } & ANXA2-F & GGTACAAGAGTTACAGCCCTTATGACA \\
\hline & ANXA2-R & CATGGAGTCATACAGCCGATCA \\
\hline \multirow[t]{2}{*}{ BIRC5 } & BIRC5-F & GCCAGATGACGACCCCATAG \\
\hline & BIRC5-R & CACCAAGGGTTAATTCTTCAAACTG \\
\hline \multirow[t]{2}{*}{ CASP3 } & CASP3-F & GCAGCAAACCTCAGGGAAAC \\
\hline & CASP3-R & AACTGCTCCTTTTGCTGTGATCT \\
\hline \multirow[t]{2}{*}{ CASP8 } & CASP8-F & TGCAAAAGCACGGGAGAAAG \\
\hline & CASP8-R & CTCTTCAAAGGTCGTGGTCAAAG \\
\hline \multirow[t]{2}{*}{ CCNA2 } & CCNA2-F & GCAGCAGAGGCCGAAGAC \\
\hline & CCNA2-R & CCAAGGAGGAACGGTGACA \\
\hline \multirow[t]{2}{*}{ CCND1 } & CCND1-F & CCCTGACGGCCGAGAAG \\
\hline & CCND1-R & AGGTTCCACTTGAGCTTGTTCAC \\
\hline \multirow[t]{2}{*}{ CDC6 } & CDC6-F & TGCAGGAGAGCTATTGAAATTGTAGA \\
\hline & CDC6-R & GGGAATCAGAGGCTCAGAAGGT \\
\hline \multirow[t]{2}{*}{$C D K N 1 A$} & CDKN1A-F & TGGAGACTCTCAGGGTCGAAA \\
\hline & CDKN1A-R & GCGGATTAGGGCTTCCTCTT \\
\hline \multirow[t]{2}{*}{$E Z R$} & EZR-F & GAAGTGCACAAGTCTGGGTACCT \\
\hline & EZR-R & СTCССАCTGGTCCCTGGTAAG \\
\hline \multirow[t]{2}{*}{ FLK1 } & FLK1-F & TCTTCTGGCTACTTCTTGTCATCATC \\
\hline & FLK1-R & GATGGACAAGTAGCCTGTCTTCAGT \\
\hline \multirow[t]{2}{*}{ ITBG1 } & ITGB1-F & GAAAACAGCGCATATCTGGAAATT \\
\hline & ITGB1-R & CAGCCAATCAGTGATCCACAA \\
\hline \multirow[t]{2}{*}{$M S N$} & MSN-F & GAAATTTGTCATCAAGCCCATTG \\
\hline & MSN-R & CCATGCACAAGGCCAAGAT \\
\hline \multirow[t]{2}{*}{$O P N$} & OPN-F & CGAGGTGATAGTGTGGTTTATGGA \\
\hline & OPN-R & CGTCTGTAGCATCAGGGTACTG \\
\hline \multirow[t]{2}{*}{$R D X$} & RDX-F & GAAAATGCCGAAACCAATCAA \\
\hline & RDX-R & GTATTGGGCTGAATGGCAAATT \\
\hline \multirow[t]{2}{*}{ VEGFA } & VEGFA-F & GCGCTGATAGACATCCATGAA C \\
\hline & VEGFA-R & CTACСТCСАССАTGCCAAGTG \\
\hline \multirow[t]{2}{*}{$V E G F D$} & VEGFD-F & TGCAGGAGGAAAATCCACTTG \\
\hline & VEGFD-R & CTCGCAACGATCTTCGTCAA \\
\hline
\end{tabular}

$1 g$ controls and N=5 $1.8 g$ hyper- $g$ samples (P1 and P31) for Western blot analyses (N=5) and quantitative real-time PCR $(\mathrm{N}=5)$, respectively. The $1 g$ controls were grown in a neighbouring equal incubator.

Vibration experiments

The detailed method was published earlier [26]. The Vibraplex vibration platform (frequency range $0.2 \mathrm{~Hz}-14 \mathrm{kHz}$ ) was used to create vibrations comparable to those occurring during parabolic flights (Fig. 1D). Corresponding vibrations to the three phases pull up $(1.8 \mathrm{~g})$, free fall $(\mu g)$, and pull out $(1.8 \mathrm{~g})$ were recorded and analysed by Schmidt [27]. These data were then used for our simulation experiments with the Vibraplex. For quantitative real-time PCR analyses, we collected N=18 samples of the groups $1 \mathrm{~g}$ and 31 parabolas of vibration. The $1 \mathrm{~g}$ controls were grown separately in a similar incubator.

\section{RNA isolation}

After the flight, the fixative was discarded and replaced by $10 \mathrm{~mL}$ of RNAlater. Subsequently the flasks were stored at $4{ }^{\circ} \mathrm{C}$ and transported to our laboratories in Berlin. The RNAlater was replaced by PBS (Invitrogen, Darmstadt, Germany). The cells were scraped off using cell scrapers (Sarstedt, Nümbrecht, Germany), transferred to tubes and pelleted by centrifugation $\left(2500 \mathrm{xg}, 10 \mathrm{~min}, 4^{\circ} \mathrm{C}\right)$. The RNeasy Mini Kit (Qiagen, Hilden, Germany) was used according to the manufacturer's instructions to isolate total RNA. RNA concentrations and quality were determined spectrophotometrically at $260 \mathrm{~nm}$ using a NanoDrop instrument (Thermo Scientific, Wilmington, DE, USA). The isolated RNA had an A260/280 ratio of >1.5.

cDNA designated for the quantitative real-time PCR was then obtained with the First Strand cDNA Synthesis Kit (Fermentas, St. Leon-Rot, Germany) using $1 \mu \mathrm{g}$ of total RNA in a $20 \mu \mathrm{L}$ reverse transcription reaction mixture.

\section{Quantitative real-time PCR}

Quantitative real-time PCR was used to determine the expression levels of the genes of interest. The Primer Express ${ }^{\circledR}$ software was utilised to design appropriate primers with a $\mathrm{T}_{\mathrm{m}}$ of about $60{ }^{\circ} \mathrm{C}$ (Table 1). The primers were synthesised by TIB Molbiol (Berlin, Germany). All assays were run on a StepOnePlus 
Fig. 2. The influence of hypergravity and vibration on cytoskeletal proteins. Western Blot analyses are shown for the proteins pan-Actin, $\beta$-Actin, and $\alpha$-Tubulin. $1 g$ : $1 g$ control cells; V: cells exposed to simulated vibration; $1.8 \mathrm{~g}$ : cells exposed to 31 parabolas of hypergravity according to the parabolic flight profile; $\# \mathrm{P}<0.05$ vs. corresponding $1 \mathrm{~g}$ control. Values are given as mean \pm standard deviation.

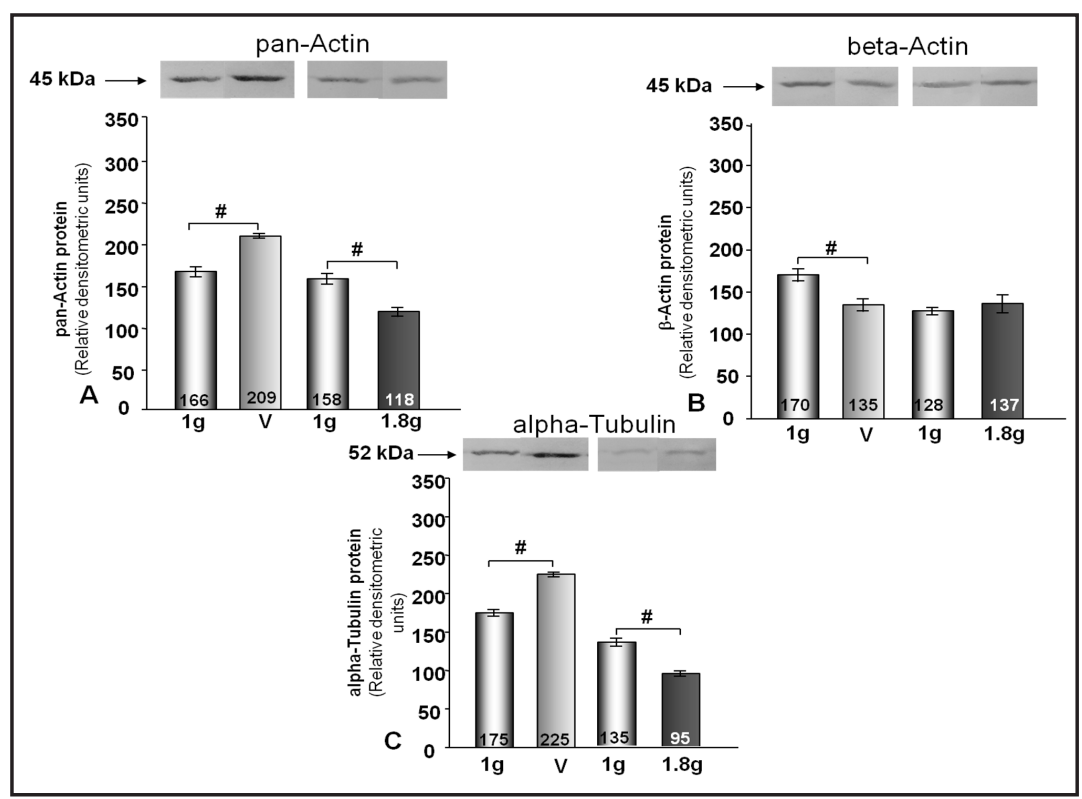

Real-Time PCR System using the Power SYBR ${ }^{\circledR}$ Green PCR Master Mix (both Applied Biosystems, Darmstadt, Germany). The reaction volume was $25 \mu \mathrm{L}$ including $1 \mu \mathrm{L}$ of template cDNA and a final primer concentration of $500 \mathrm{nM}$. PCR conditions were as follows: $10 \mathrm{~min}$ at $95^{\circ} \mathrm{C}, 40$ cycles of $30 \mathrm{~s}$ at $95^{\circ} \mathrm{C}$ and $1 \mathrm{~min}$ at $60^{\circ} \mathrm{C}$, followed by a melting curve analysis step (temperature gradient from $60^{\circ} \mathrm{C}$ to $95^{\circ} \mathrm{C}$ with $+0.3^{\circ} \mathrm{C}$ per cycle).

If all amplicons showed one single $\mathrm{T}_{\mathrm{m}}$ similar to the one predicted by the Primer Express software the PCR reactions were considered specific. Every sample was measured in triplicate and we utilized the comparative $\mathrm{C}_{\mathrm{T}}\left(\Delta \Delta \mathrm{C}_{\mathrm{T}}\right)$ method for the relative quantification of transcription levels. 18S rRNA was used as a housekeeping gene to normalize our expression data.

\section{Western blot analysis}

SDS-PAGE, immunoblotting and densitometry were carried out on six replicates following routine protocols [28-30]. Antibodies against the following antigens were used: $\alpha$-tubulin, pan-actin, and $\beta$-actin, moesin and radixin (dilution 1:1000, all antibodies were purchased by Cell Signaling Technology Inc., MA, USA). For the densitometric quantification of the bands, the stained membranes were scanned and analysed using the Image J (http://rsb.info.nih.gov/ij/) software [31]. Since no suitable protein was found which could serve as a loading control under the investigated experimental conditions, we carefully loaded equal amounts of protein $(40 \mu \mathrm{g}$ in $10 \mu \mathrm{L})$ onto each gel lane and normalized the densitometric data to this value.

\section{Statistical analysis}

All statistical analyses were performed using the SPSS 16.0 software (SPSSS, Inc, Chicago, IL, USA). We employed either one-way ANOVA or the Mann-Whitney-U-test where applicable. Differences were considered significant at the level of $p<0.05$. All data are represented as means \pm standard deviation.

\section{Results}

\section{Hypergravity and Vibration}

Changes on the Protein Level. In order to investigate the impact of hypergravity and vibration on the protein levels of selected genes of interest, we performed Western Blot analyses on ECs exposed to both conditions as described in the methods section. The Panactin and alpha-tubulin contents of the cells were significantly elevated by vibration and significantly down-regulated by hypergravity. In contrast, the beta-actin protein was reduced by vibration, but hypergravity did not change its amount (Fig. 2).

Furthermore, we examined two proteins belonging to the ERM-family of regulators of membrane-cortex interactions and signaling: ezrin and moesin. Ezrin protein was strongly 
Fig. 3. The influence of hypergravity and vibration on ERM proteins. Western Blot analyses are shown for the proteins ezrin and moesin. $1 g$ : $1 g$ control cells; V: cells exposed to simulated vibration; $1.8 g$ : cells exposed to 31 parabolas of hypergravity according to the parabolic flight profile, $\# \mathrm{P}<0.05$ vs. corresponding $1 \mathrm{~g}$ control. Values are given as mean \pm standard deviation.

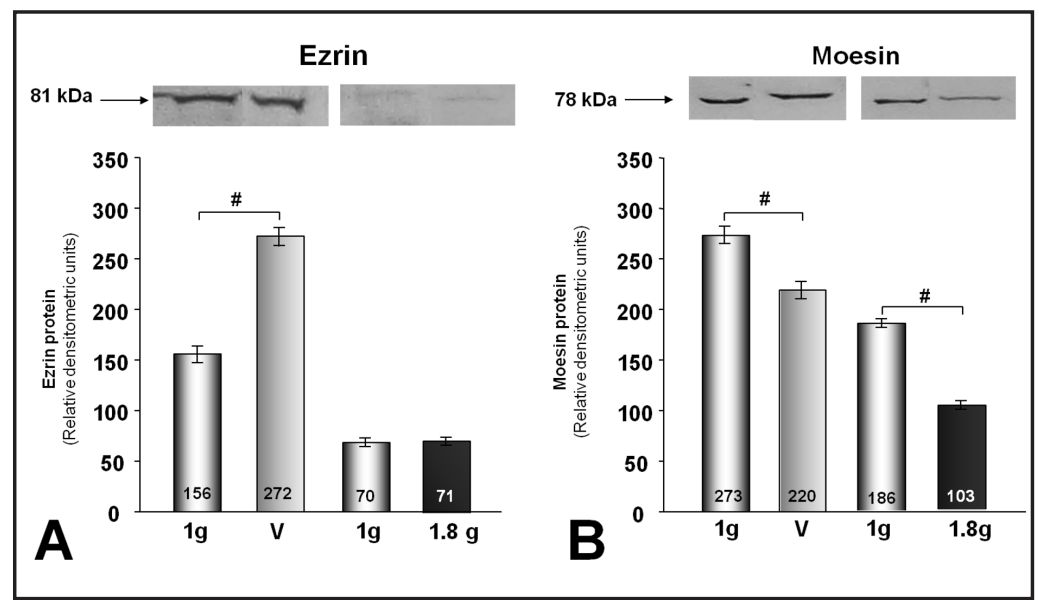

and significantly elevated in EC cultured under conditions of vibration, cultivation under hypergravity of $1.8 \mathrm{~g}$ did not induce changes. In contrast, moesin protein was significantly reduced by both vibration and hypergravity in ECs after 2 hours (Fig. 3).

Changes on the Transcriptional Level. In addition to the genes belonging to the proteins analyzed in the Western Blots, we choose further transcripts of interest, mainly those which are involved in the regulation of the cell cycle, angiogenesis, (3D) proliferation, cellular signalling, apoptosis and extracellular matrix. The list comprised ACTB, CCNA2, CCND1, CDC6, CDKN1A, VEGFA, VEGFD, FLK1, EZR, MSN RDX, ITGB1, SPP1 (OPN), CASP3, CASP8, ANXA1, $A N X A 2$, and BIRC5 (Survivin).

$A C T B$ gene expression was significantly diminished after $2 \mathrm{~h}$ by hypergravity. Vibration also reduced the expression of $A C T B$ significantly (Fig. 4A).

Transcription of CCNA2 and CCND1 was not affected by hypergravity, while CDC6 gene expression was significantly decreased after $2 \mathrm{~h}$ and CDKN1A transcript levels were significantly suppressed after $20 \mathrm{~s}$ of hypergravity. Except for CCNA2, the other three transcripts were found to be down-regulated by vibration (Fig. 4B).

Hypergravity had an impact on all three investigated angiogenic genes. Both VEGFA and VEGFD were significantly down-regulated in the 1P (hypergravity simulation of one parabola) group, but only VEGFD remained suppressed in the 31P (hypergravity simulation of 31 parabolas) group. FLK1, on the other hand was clearly, although not mathematically significantly, up-regulated in the 1P group and reverted back to control levels after $2 \mathrm{~h}$ of hypergravity. Vibration decreased VEGFA- and FLK1-expression significantly (Fig. 4C).

Of the ERM genes, only EZR showed a reaction to hypergravity and vibration. In both $1 \mathrm{P}$ and 31P groups as well as in cells grown under vibration EZR expression was significantly decreased in comparison to the control groups (Fig. 4D).

ITBG1 transcript levels were decreased in both hypergravity groups as well as in cells exposed to vibration. OPN expression on the other hand, did not change significantly under hypergravity, but also decreased significantly under vibration (Fig. 4E).

$C A S P 3$ and -8 gene expression were significantly decreased in the hypergravity 1 P group, but while CASP3 remained suppressed in the $31 \mathrm{P}$ cells, CASP8 rose back to normal levels. Both transcripts were downregulated by vibration. Similarly, ANXA1 and ANXA2 expression were significantly reduced in hypergravity $1 \mathrm{P}$ cells, but no significant difference was found in 31P cells compared to $1 \mathrm{~g}$ control cells. Vibration only decreased $A N X A 2$ expression significantly but did not affect ANXA1. BIRC5 did not show any significant effects in hypergravity, although a similar tendency for decreased transcription was observed. Vibration reduced BIRC5 transcript levels significantly (Fig. 4F).

\section{Parabolic Flight}

Changes on the Transcriptional Level. To compare the results from the isolated hypergravity and vibration experiments with the effects from a real parabolic flight, we also 
Wehland et al.: Effects of Parabolic Flight Maneuvers on Endothelial Cells

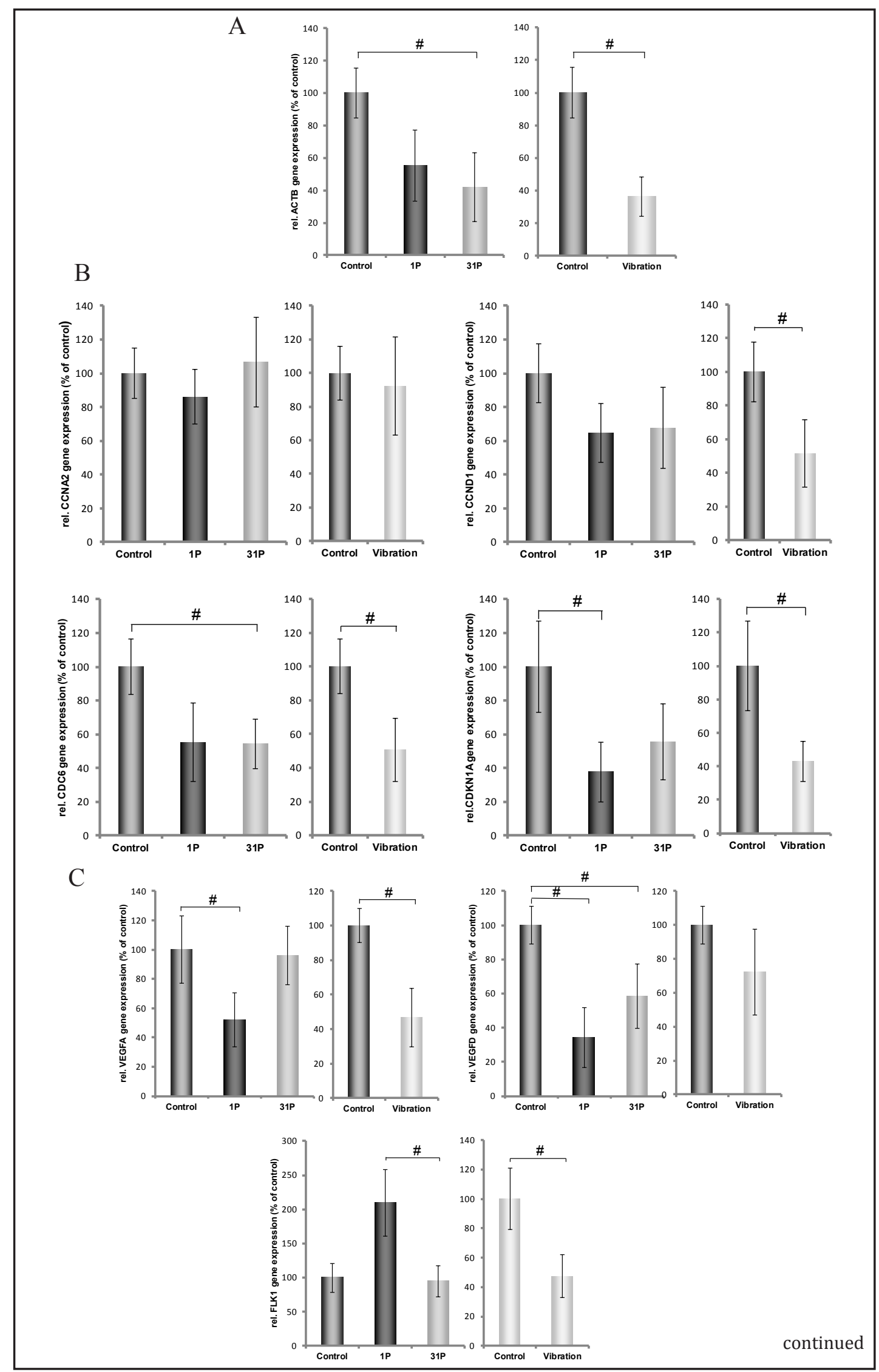




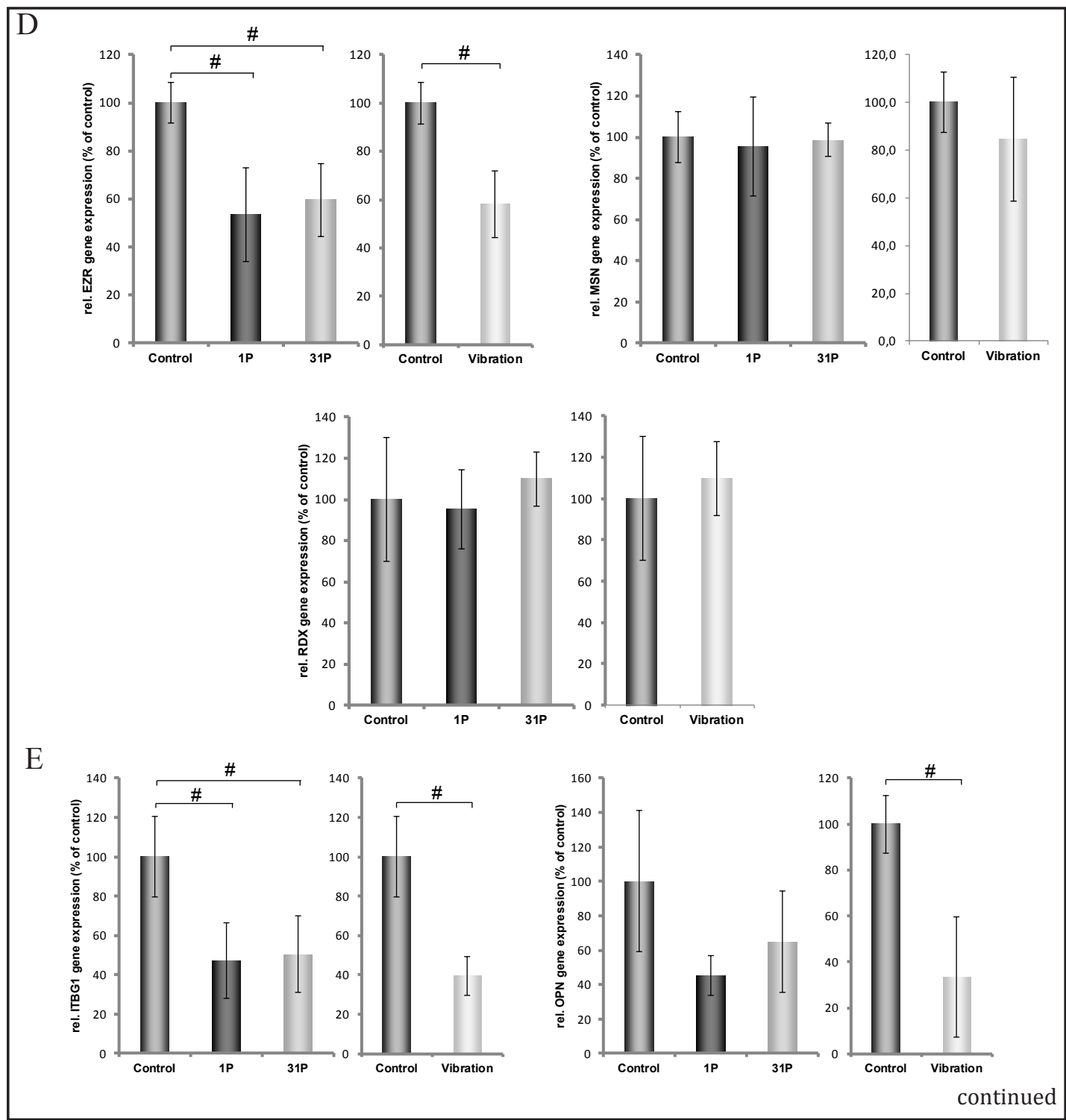

measured the gene expression levels of our selected transcripts using the quantitative realtime PCR technique.

Although we observed a general tendency of transcriptional upregulation of ACTB during parabolic flight, these changes did not prove to be statistically significant (Fig. 5A).

After one and 31 parabolas of real microgravity CCNA2, CCND1, CDC6, and CDKN1A were all strongly and significantly up-regulated in comparison to the $1 g$ control cells (Fig. 5B).

Both VEGFA and VEGFD expression was significantly elevated after 31 parabolas, while FLK1 was clearly down-regulated after one parabola and reverted back to control levels after 31 parabolas (Fig. 5C).

Under the conditions of parabolic flight the transcription of EZR and MSN showed an identical pattern. After one parabola both genes were strongly up-regulated, and transcription decreased after 31 parabolas, but still remained significantly higher than in $1 \mathrm{~g}$ control cells (Fig. 5D).

Levels of ITGB1 transcript did not change significantly during the whole parabolic flight, whereas $O P N$ gene expression increased over time, reaching a significant peak after the $31^{\text {st }}$ parabola (Fig. 5E).

$C A S P 3,-8$, and ANXA1 transcription were significantly upregulated after the first parabola and remained at this level until after the $31^{\text {st }}$ parabola. In contrast to this ANXA2 


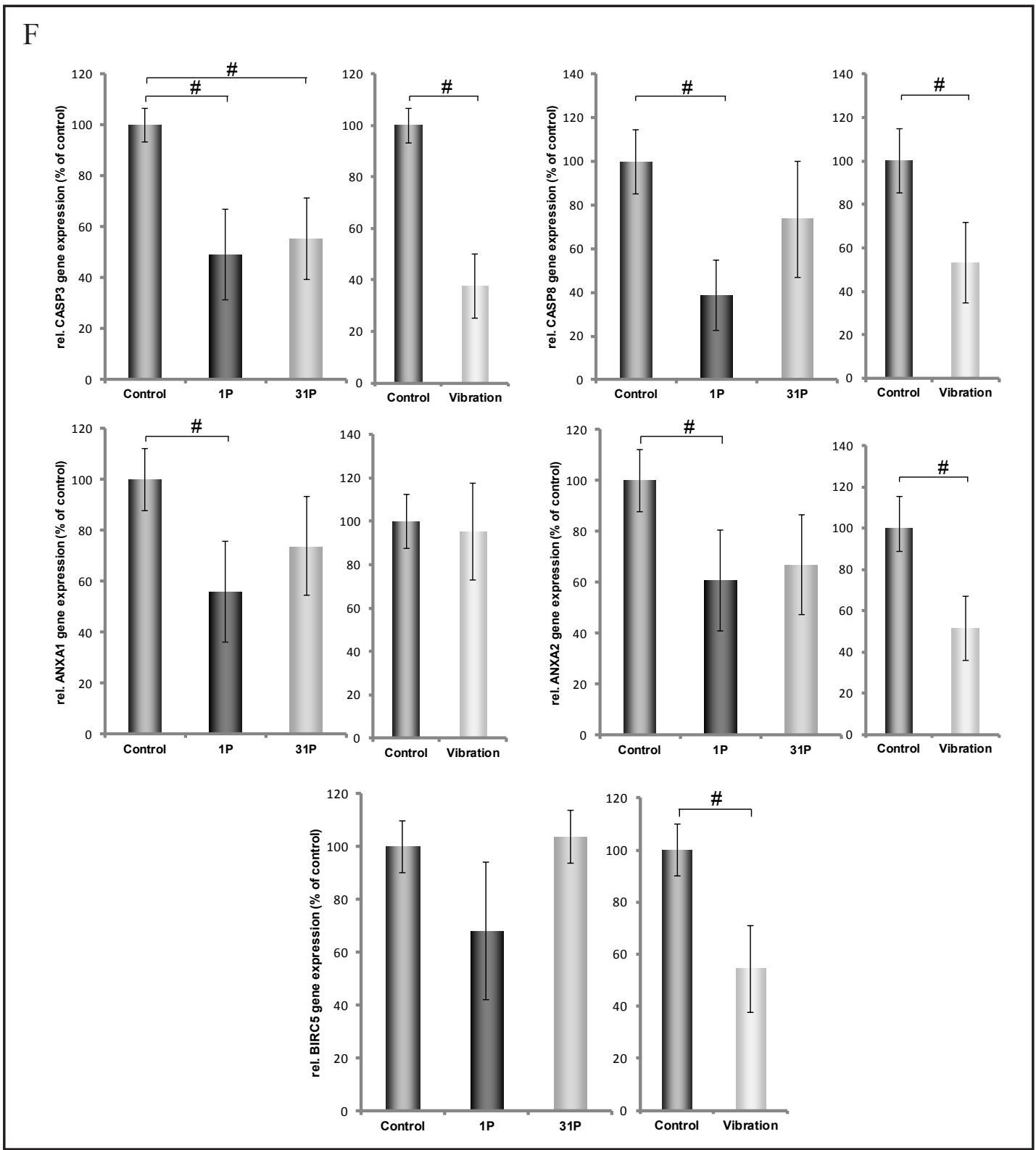

Fig. 4. Quantitative real-time PCR - vibration and hypergravity. Quantitative real-time PCR analyses are shown for A: gene of the cytoskeleton, B: genes involved in cell cycle regulation, C: genes involved in angiogenesis, D: ERM genes, E: extracellular matrix genes, and F: genes involved in apoptosis. 1P: 1 parabola of hypergravity according to the parabolic flight profile; 31P: 31 parabolas of hypergravity according to the parabolic flight profile; $\# \mathrm{P}<0.05$ vs. corresponding $1 g$ control; ${ }^{*} \mathrm{P}<0.05$ vs. $\mathrm{P} 1$. Values are given as mean \pm standard deviation.

and BIRC5 gene expressions were strongly elevated after one parabola and decreased after the $31^{\text {st }}$ parabola, while still remaining significantly elevated compared to $1 \mathrm{~g}$ control cells (Fig. 5F).

\section{Discussion}

We have shown previously that cells, when exposed to a parabolic flight, undergo severe changes already after the first parabola $[11,26]$. During parabolic flights, periods 


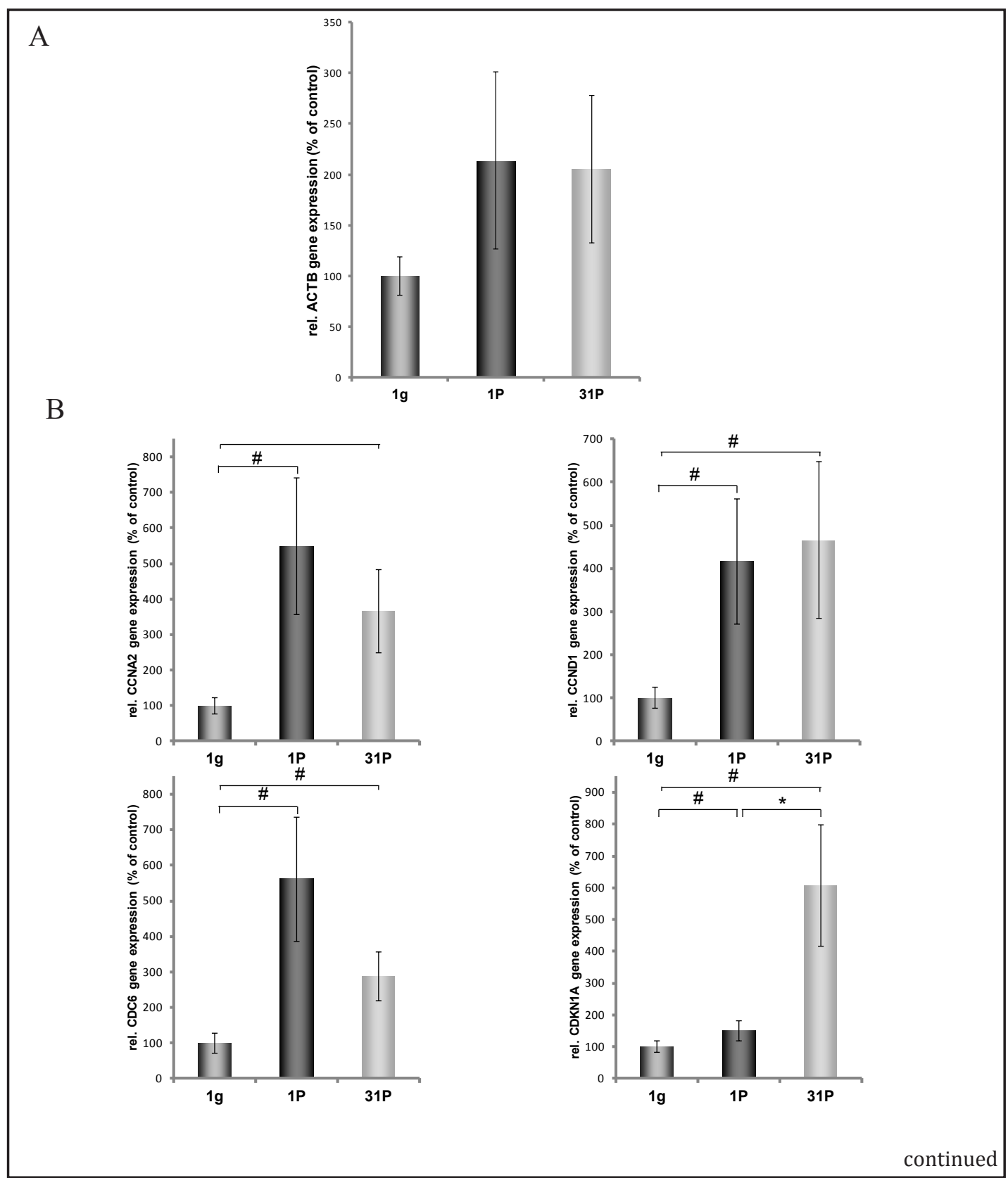

of micro- and hypergravity alternate and are accompanied by vibrations. In this study, we aimed to investigate to what extent hypergravity and vibrations in addition to microgravity influence the protein- and gene expression of the cell line EA.hy926 during a parabolic flight. Therefore we exposed the cells to the various conditions separately and analyzed genes involved in the cytoskeleton (ACTB, EZR, MSN, RDX), cell cycle regulation (CCNA2, CCND1, $C D C 6, C D K N 1 A)$, angiogenesis (VEGFA, VEGFD, FLK1), cell adhesion, migration and signalling (EZR, MSN, RDX), apoptosis (CASP3, CASP8, ANXA1, ANXA2, BIRC5), as well as extracellular matrix (ECM) (ITGB1, OPN) (Table 2).

\section{Cytoskeleton}

$A C T B$ gene and protein expression correlate directly under vibration, with both showing a significant decrease. Interestingly, also hypergravity induced a reduction in $A C T B$ gene expression, while ACTB protein levels remained unchanged. Tubulin protein was 


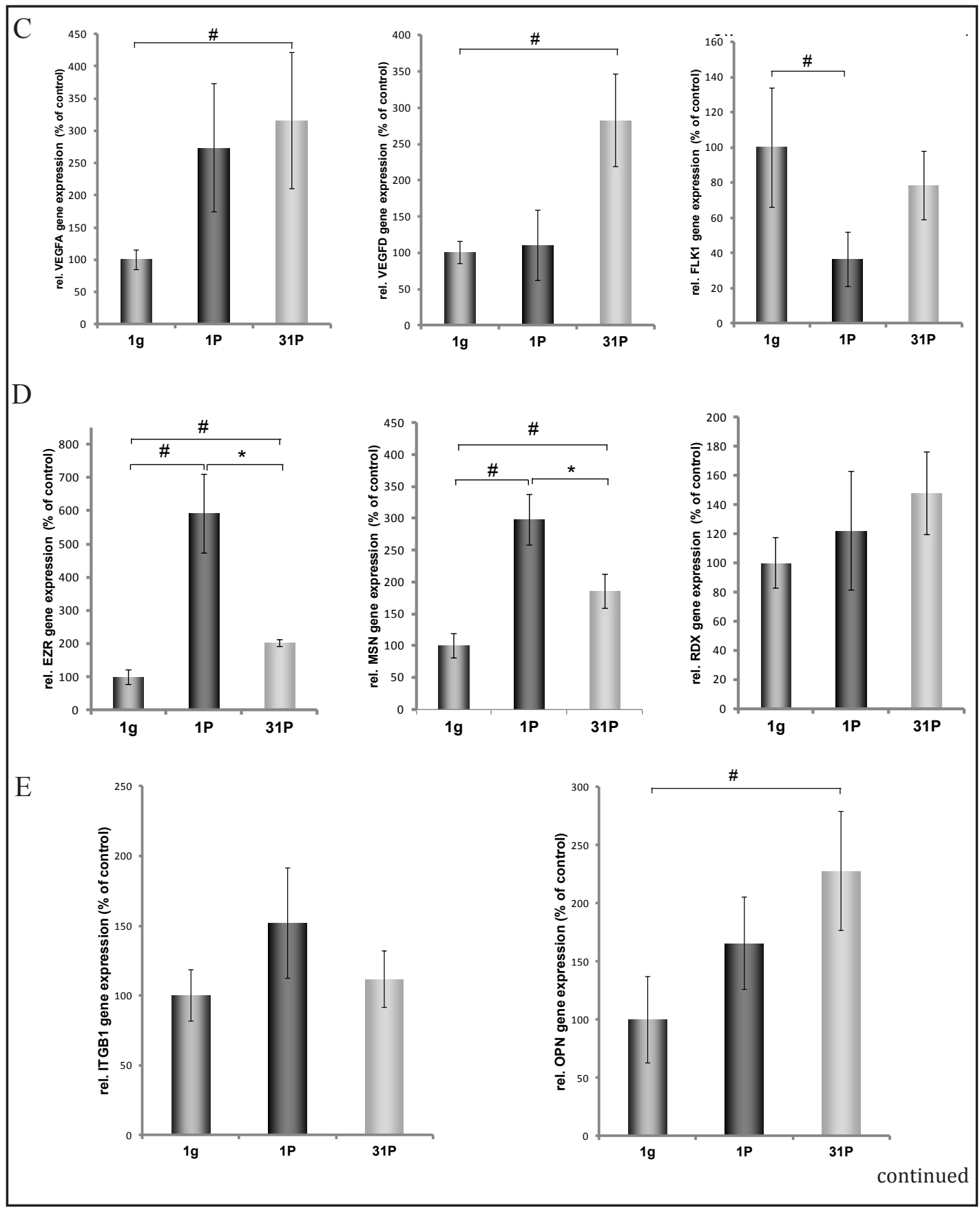

downregulated in hypergravity and upregulated by vibration. This is in good agreement with earlier studies, where we showed similar tendencies for TUBB gene expression [26]. The results for the parabolic flight correspond with earlier observations [11, 26], which showed that cytoskeletal proteins underwent a drastic rearrangement, but did not change their concentration inside the cells. These results suggest that hypergravity/vibration are severe stress factors for the cells and induce a deterioration of the cytoskeletal network.

The ezrin (EZR), radixin (RDX) and moesin (MSN) proteins are usually referred to as the ERM proteins and play a crucial role in the organization and maintenance of the cell cortex, the interface between the extracellular environment and the cytoskeleton [32]. The three proteins share a high similarity in their amino acid composition, yet there are some differences that hint towards specialized functionality. Ezrin is mostly found in epithelial 


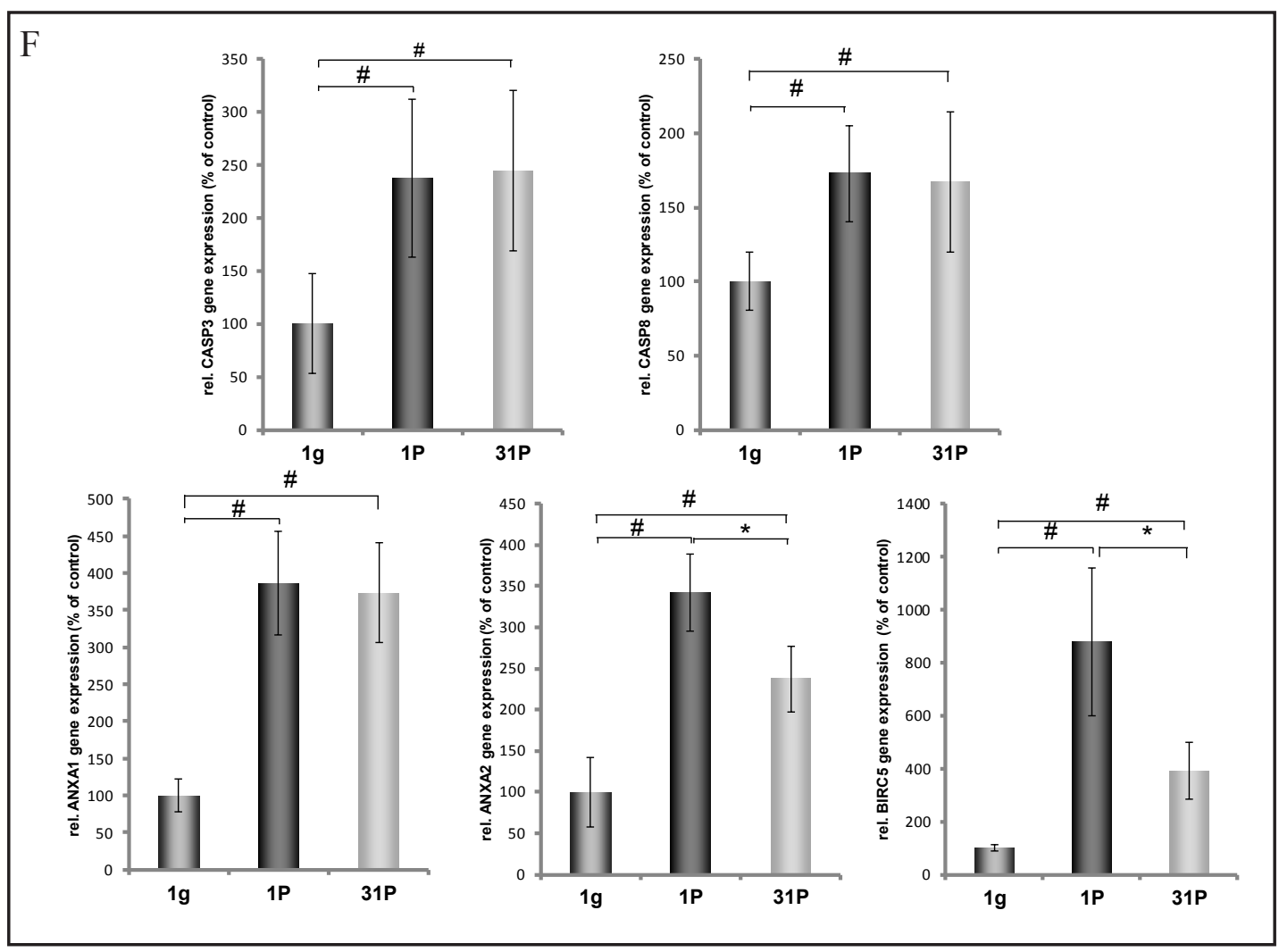

Fig. 5. Quantitative real-time PCR - real microgravity. Quantitative real-time PCR analyses are shown for A: gene of the cytoskeleton, B: genes involved in cell cycle regulation, C: genes involved in angiogenesis, D: ERM genes, E: extracellular matrix genes; and F: genes involved in apoptosis. 1P: cells after one flown parabola; $31 \mathrm{P}$ : cells after 31 flown parabolas; $\# \mathrm{P}<0.05$ vs. corresponding $1 g$ control; ${ }^{*} \mathrm{P}<0.05$ vs. $\mathrm{P} 1$. Values are given as mean \pm standard deviation.

cells, moesin in endothelial cells, and radixin in hepatocytes [33-35]. They all share a common appearance and are composed of an amino-terminal FERM (Four point one, ERM) domain, mediating membrane association, an $\alpha$-helix rich middle, and an F-actin binding site (C-ERMAD, the C-terminal ERM-association domain) at the carboxy terminus [36]. The best documented and probably most important function of the ERMs is the bundling and arrangement of F-actin filaments parallel to the cell membrane, but numerous studies suggest additional roles for them. ERMs have been implicated in Rho signalling [37-40] and, interestingly, lumen morphogenesis [41-43]. We detected a down-regulation of the corresponding ERM genes by hypergravity/vibration while real microgravity leads to their up-regulation. This might explain the observed actin rearrangement after one parabola and may also be one first step towards tube formation as seen in long-term RPM experiments, whereas under hypergravity or vibrations none such effects were present.

\section{Angiogenesis}

The proteins VEGF-A and -D, encoded by VEGF- $A$ and VEGFD genes, belong to the vascular endothelial growth factor family comprising the five members VEGFA, - B, -C, -D, and F as well as placenta growth factor (PIGF) [44-46]. VEGF-A is the most important type of VEGF for angiogenesis, i.e. the formation of new vessels from existing ones [44]. When VEGF proteins are secreted, they are bound by tyrosine kinase receptors. For VEGF-A and VEGF-D FLK-1, also known as VEGFR-2, encoded by FLK1, is the most important receptor and it is mainly expressed in vascular endothelial cells [45]. The VEGF/VEGFR-2 regulatory system plays a central role in angiogenesis and is also involved in various other biological functions, such 


\begin{tabular}{|c|c|c|c|c|c|c|}
\hline \multicolumn{7}{|c|}{ Gene expression } \\
\hline \multirow[b]{2}{*}{ Biological Function } & \multirow[b]{2}{*}{ Gene Symbol } & \multicolumn{2}{|c|}{ Hypergravity } & \multirow{2}{*}{$\begin{array}{l}\text { Vibration } \\
31 P\end{array}$} & \multicolumn{2}{|c|}{ Parabolic Flight } \\
\hline & & & $31 P$ & & $1 P$ & $31 P$ \\
\hline Cytoskeleton & $A C T B$ & $(-)$ & & - & & \\
\hline \multirow{5}{*}{ Cell cycle regulation } & $A C I D$ & $(-)$ & - & - & $(+)$ & $(+)$ \\
\hline & CCNA2 & & & & + & + \\
\hline & CCND1 & $(-)$ & $(-)$ & - & + & + \\
\hline & CDC6 & $(-)$ & & - & + & + \\
\hline & CDKN1A & - & $(-)$ & - & + & + \\
\hline \multicolumn{7}{|l|}{ Angiogenesis } \\
\hline & $\begin{array}{l}\text { VEGFA } \\
\text { VEGFD }\end{array}$ & :- & - & $(-)$ & $(+)$ & $\begin{array}{l}+ \\
+\end{array}$ \\
\hline & FLK1 & $(+)$ & & - & - & \\
\hline \multicolumn{7}{|l|}{$\begin{array}{l}\text { Cell adhesion, migration, } \\
\text { and signalling }\end{array}$} \\
\hline & $E Z R$ & - & - & - & + & + \\
\hline & $\begin{array}{l}M S N \\
P D X\end{array}$ & & & & + & + \\
\hline \multicolumn{7}{|l|}{ Extracellular matrix } \\
\hline & ITBG1 & & & & & \\
\hline \multirow{6}{*}{ Apoptosis } & & $(-)$ & $(-)$ & - & $(+)$ & + \\
\hline & CASP3 & - & - & - & + & + \\
\hline & CASP8 & - & & - & + & + \\
\hline & ANXA1 & - & & & + & + \\
\hline & ANXA2 & - & & - & + & + \\
\hline & BIRC5 & & $(-)$ & - & + & + \\
\hline \multicolumn{7}{|c|}{ Protein Content } \\
\hline \multirow{5}{*}{$\frac{\text { Biological Function }}{\text { Cytoskeleton }}$} & & \multicolumn{2}{|c|}{$\begin{array}{l}\text { Hypergravity } \\
210\end{array}$} & Vibration & \multirow{2}{*}{\multicolumn{2}{|c|}{$\begin{array}{l}\text { Parabolic Fligh } \\
1 P \\
1 P\end{array}$}} \\
\hline & Protein Name & $1 P$ & $31 P$ & & & \\
\hline & pan-Actin & n.d. & - & + & & \\
\hline & beta-Actin & n.d. & & & n.d. & n.d. \\
\hline & alpha-Tubulin & n.d. & - & + & & \\
\hline \multirow{2}{*}{$\begin{array}{l}\text { Cell adhesion, migration, } \\
\text { and signalling }\end{array}$} & Ezrin & n.d. & & + & n.d. & n.d. \\
\hline & Moesin & n.d. & - & - & n.d. & n.d. \\
\hline
\end{tabular}

Table 2. A brief summary of gene-expression and protein content data

as wound healing and burn injury, regulation of endothelial growth or pathophysiological processes such as tumor vascularisation, and is also a survival factor for endothelial cells [47-50].

In our hypergravity experiments, both VEGFA and VEGFD were down-regulated and, possibly as a reaction to VEGF-A and -D depletion, FLK1 gene expression was up-regulated. This seems to hint towards the induction of a non-angiogenic phenotype by this kind of treatment. In contrast to this, real microgravity seems to promote angiogenesis, by upregulating both growth factors and their receptor.

\section{Extracellular matrix}

Both the ITGB1 and the OPN gene expression were decreased in hypergravity or vibration. Integrins mediate cell adhesion to ECM and cell-cell contacts. They also play an important role in development and immune responses, and are also vital in the development of many human diseases [51]. Osteopontin, encoded by OPN, is secreted by the cells and is a part of the ECM. As such it is also a ligand for different integrins [52, 53]. Besides being implicated in chemotaxis and cell activation it was also shown, that osteopontin is an important antiapoptotic factor, as it is able to block programmed cell death in stress-exposed endothelial cells [54-56]. The observation, that both ITGB1 and OPN genes are down-regulated under hypergravity and vibration and up-regulated in microgravity shows that alterations in gravity have an influence on cell adhesion and cell survival with microgravity inducing protective effects.

\section{Apoptosis}

The CASP3, CASP8, ANXA1, ANXA2, and BIRC5 (also known as Survivin) genes are all implied in the process of programmed cell death, also called apoptosis. The process of apoptosis manifests itself by an internal proteolytic digestion which leads to a breakdown 
of cellular function and infrastructure. Possible triggers of apoptosis are manifold and can range from lack of growth factors, DNA damage, ionizing radiation, ischemic injury, and more [57-62].

The majority of apoptotic pathways are mediated by a family of cysteine aspartatespecific proteases, commonly called the "caspases". These caspases can be grouped into the initiator (caspase-8 and -10) and the effector caspases (caspases-3, -6, and -7). CASP8 and CASP3 are involved into the so-called extrinsic pathway. Here, specific death-receptors on the cells surface trigger a cascade which first activates the initiator caspase-8, which in turn cleaves and activates the executioner caspase-3. Caspases disrupt many proteins involved in cytoskeletal integrity and cell-cell communication, they attack the endoplasmatic reticulum, the golgi apparatus and the nucleus itself [62-64].

ANXA1 and ANXA2 belong to the annexin superfamily of calcium or calcium and phospholipid binding ("annexing") proteins, which comprises a total of 13 members [65]. ANXA1 and ANXA2 expression is highly abundant in smooth muscle and endothelial cells $[66,67]$. The annexins have multiple physiological roles: they can regulate the plasma membrane architecture, interact with the actin cytoskeleton and are also involved in the regulation of intracellular $\mathrm{Ca}^{2+}$ homeostasis [68-70]. Interestingly, ANXA1 in particular was also reported to be a regulator of cell proliferation and apoptosis. It has been shown, that ANXA1, by being a substrate for the EGF rector tyrosine kinase, is an inhibitor of EGFdependent cell proliferation [71, 72]. Furthermore many, but not all studies indicated that ANXA1 is an inducer of apoptosis. Overexpression of ANXA1 in monocytic cells led to an enhanced TNF- $\alpha$-induced apoptosis. 5 days after transfection with full-length ANXA1, about $70 \%$ of these cells underwent apoptosis and changes in ANXA1 expression had an effect on caspase-3 activity. Exogenous ANXA1 promoted $\mathrm{Ca}^{2+}$ influx into human neutrophils and accelerated apoptosis [73-75].

BIRC5 (also known as survivin) is an inhibitor of apoptosis proteins and is involved in cell division and apoptosis suppression [76-78]. The exact mechanism of action of survivin is not completely understood, but studies have shown that it directly interacts with effector caspases-3 and -7, thus preventing their activation. Furthermore, it can also interfere with the caspase-independent AIF pathway of cell death [79, 80].

In this work we have observed, that the proapoptotic genes CASP3, CASP8, ANXA1, and $A N X A 2$ as well as the antiapoptotic gene BIRC5 were downregulated in hypergravity/ vibration and upregulated in real microgravity during a parabolic flight. It has been observed earlier, that endothelial cells, when exposed to prolonged simulated microgravity on an RPM for up to $72 \mathrm{~h}$, develop apoptosis [10], therefore our results for the parabolic flight might represent the first steps, still contained by the similarly overexpressed BIRC5, towards the development of overt programmed cell death at a later stage, which is supported by the fact that EC on a parabolic flight did not show any visible sign of apoptosis [26]. Our results with cells exposed to hypergravity/vibration seem to hint towards the induction of a nonapoptotic cell state, which might have further impact for cell culture or tissue engineering techniques. This is the first time this kind of analysis was performed on endothelial cells and further work is required to study these effects in more detail.

\section{Cell Cycle Regulation}

Cyclin A2, encoded by CCNA2, and cyclin D1, ecoded by CCND1, belong to the big family of cyclins. In general, cyclins regulate cell cycle progression. This is mediated by the sequential activation of different cyclins. They all bind, activate, and determine the substrate specificity of their binding partners, the serine-threonin kinases, also called cyclin-dependent kinases (Cdks) [81, 82].

The cyclins can be subdivided into the different calluses A to I, and T, which have different functions. While cyclin A1 is exclusively expressed in testis and germ line, cyclin A2 is found practically ubiquitously in cultured cells and different cancers [83-85]. By interacting either with Cdk2 or Cdk1 it is able to control both $S$ phase and $G_{2} / M$ transition, respectively. 
During the $\mathrm{S}$ phase cyclin $\mathrm{A} 2$ regulates the DNA synthesis, while it acts as a trigger for cyclin B1-Cdk1 activation at the $\mathrm{G}_{2} / \mathrm{M}$ transition [86-89].

The D-type cyclins are important players in the entry into the G1/S phase of the mitotic cell cycle, but they have also been implicated in differentiation, regulation of transcription or apoptosis [90-92].

CDKN1A, also known as $\mathrm{p} 21^{\text {Waf1/Cip1/Sdi1 }}$, functions as an inhibitor of a broad spectrum of Cdks $[93,94]$ and was first identified as one component of a complex together with cyclin D1, a Cdk, and PCNA [95]. CDKN1A is involved in a variety of biological processes. Most prominently it is a negative regulator of cell cycle progression, which maintains cells in the G0 phase upon accumulation [96, 97]. Furthermore, CDKN1A is also implicated in apoptosis. Generally, downregulation of CDKN1A leads to p53-dependent apoptosis. DNA damage, for example, induces cleavage of CDKN1A by caspase 3 , which can promote apoptosis in growtharrested cancer cells [98]. In addition, it was also shown to be involved in DNA repair and senescence $[99,100]$.

Interestingly, a recent study investigating $\mathrm{T}$ lymphocytes on a $2 \mathrm{D}$ clinostat and on a parabolic flight also reported an increase in CDKN1A expression under both conditions [101].

CDC6, cell division cycle 6, is a central and essential factor of DNA replication and highly conserved in all eukaryotic organisms. Downregulation of CDC6 levels have been shown to prevent $G_{1}$ cells from progression into $S$ phase $[102,103]$. Furthermore it was found that lack of CDC6 stops cell proliferation and induces apoptosis [104, 105].

Our results show that these important genes for cell cycle regulation are transcribed in an altered way under both hypergravity/vibration and conditions of a parabolic flight compared to the static $1 \mathrm{~g}$ control. The expression patterns indicate that cells cultured under hypergravity or vibration alone undergo changes which lead to a slowed down cell cycle, while parabolic flights (hypergravity + vibration + microgravity) induce proliferation.

\section{Conclusions}

In the present study we have shown that $A C T B, E Z R, M S N, R D X, C C N A 2, C C N D 1, C D C 6$, CDKN1A, VEGFA, VEGFD, FLK1, ITGB1, OPN, CASP3, CASP8, ANXA1, ANXA2, and BIRC5 are expressed in a gravity- and/or vibration-dependent manner in endothelial cells (for a concise overview see Table 2). It is noteworthy, that isolated hypergravity and vibration have diametrically different effects on the expression of these genes compared to the exposure to parabolic flight. Up to now, the exact mode of sensing the three conditions applied is not yet completely elucidated. So far suggested mechanisms can be divided into centralized/ direct and decentralized/indirect models. Centralized models comprise the action of mechanosensitive ion channels [106-108], mechanosensitive protein kinases [109, 110], or caveolae $[111,112]$. In addition, evidence for indirect mechanisms involving integrins [113115] or the cytoskeleton [116] have also been reported. We hypothesize that gravisensing is mainly mediated by an indirect mechanism involving the cytoskeleton, because we had observed a rearrangement of various cytoskeletal components after one parabola [11] as well as after prolonged exposure of endothelial cells to simulated microgravity on an RPM for 5 to 7 days $[9,10,12,13]$. Furthermore, centrifugation and parabolic flights have diametrically different effects on the expression of the genes investigated. This seems to hint towards an ability of the cells to sense different levels of gravity and not only gravitational changes. But the signal exerted by microgravity is able to override the effects of the hypergravity phases and the vibration, because the parabolic flight results resemble more the RPM than the centrifugation results. Therefore, microgravity represents the strongest stimulus during this kind of experiment. 
Wehland et al.: Effects of Parabolic Flight Maneuvers on Endothelial Cells

\section{Abbreviations}

2D (two-dimensional); 3D (three-dimensional); ACTB ( $\beta$-actin); ANOVA (analysis of variance); ANXA1 (annexin A1); ANXA2 (annexin A2); BIRC5 (survivin); CASP3 (caspase 3); CASP8 (caspase 8); CCNA2 (cyclin A2); CCND1 (cyclin D1); CDC6 (cell division cycle 6 homolog); CDKN1A (cyclin-dependent kinase inhibitor 1A); cDNA (complementary DNA); C-ERMAD (C-terminal ERM-association domain); $\mathrm{C}_{\mathrm{T}}$ (threshold cycle); DLR (Deutsches Zentrum für Luft- und Raumfahrt); EC (endothelial cells); ERK1/2 (extracellular signalregulated kinase 1/2); ERM (Ezrin-Radixin-Moesin); ET-1 (endothelin 1); EZR (ezrin); FERM (Four point one, ERM); FLK1 (VEGF-receptor 2); Hz (Hertz); ITGB1 (integrin $\beta 1$ ); mg (milligram(s));mL (millilitre(s)); MSN (moesin); MuSIC (Multi Sample Incubator Centrifuge); OPN(osteopontin); P (parabola); PBS (phosphate buffered saline); PCNA (Proliferating-CellNuclear-Antigen); PCR (polymerase chain reaction); RDX (radixin); RNA (ribonucleic acid); RPM (Random Positioning Machine); RWV (Rotating Wall Vessel); s (seconds); SDS-PAGE (sodium dodecyl sulfate polyacrylamide gel electrophoresis); $\mathrm{T}_{\mathrm{m}}$ (annealing temperature); TUBB (tubulin $\beta$ ); VEGFA (vascular endothelial growth factor A); VEGFD (vascular endothelial growth factor $\mathrm{D})$.

\section{Competing Interests}

The authors declare that they have no competing interests.

\section{Acknowledgements}

This study was supported by the German Space Agency DLR (BMWi grants 50WB0824 and 50WB1124) as well as by the European Space Agency (ESA grant CORA-GBF-2010-203 with contract number 4000102119) and by Aarhus University, Denmark. We like to thank Dr. Jessica Pietsch (OVGU Magdeburg, Germany), Dr. Nicole Vagt (University of Bonn, Germany), Dr. Claudia Ulbrich (University of Hohenheim, Germany), Dr. Nils Magnusson (Aarhus University, Denmark), Dr. Peter Richter (University of Erlangen, Germany, PD Dr. Marcel Egli (ETH Zurich, Switzerland), Stephane Richard (ETH Zurich, Switzerland), dipl. ing. Ganna Aleshcheva (OVGU Magdeburg, Germany) and dipl. ing. Kriss Westphal (ETH Zurich, Switzerland) for their participation in the parabolic flights and their help with the flight experiments.

\section{References}

1 Pearson JD: Normal endothelial cell function. Lupus 2000;9:183-188.

2 Alliegro MC: Pigpen and endothelial cell differentiation. Cell Biol Int 2001;220:2077-2084.

-3 Dvorak HF: Vascular permeability factor/vascular endothelial growth factor: a critical cytokine in tumor angiogenesis and a potential target for diagnosis and therapy. J Clin Oncol 2002;20:4368-4380.

4 Schiffrin EL: The endothelium and control of blood vessel function in health and disease. Clin Invest Med 1994;17:602-620.

5 Mantovani A, Bussolino F, Introna M: Cytokine regulation of endothelial cell function: From molecular level to the bedside. Immunol Today 1997;18:231-240.

6 Buravkova L, Romanov Y, Rykova M, Grigorieva O, Merzlikina N: Cell-to-cell interactions in changed gravity: Ground-based and flight experiments. Acta Astronaut 2005;57:67-74.

7 Sangha DS, Han S, Purdy RE: Simulated microgravity upregulates an endothelial vasoconstrictor prostaglandin. J Appl Physiol 2001;91:789-796.

8 Infanger M, Ulbrich C, Baatout S, Wehland M, Kreutz R, Bauer J, Grosse J, Vadrucci S, Cogoli A, Derradji H, Neefs M, Küster S, Spain S, Paul M, Grimm D: Modelled gravitational unloading induced downregulation of endothelin-1 in human endothelial cells. J Cell Biochem 2007;101:1439-1455. 
Wehland et al.: Effects of Parabolic Flight Maneuvers on Endothelial Cells

9 Ulbrich C, Westphal K, Baatout S, Wehland M, Bauer J, Flick B, Infanger M, Kreutz R, Vadrucci S, Egli, M, Cogoli, A, Derradji H, Pietsch J, Paul M, Grimm D: Effects of basic fibroblast growth factor on endothelial cells under conditions of simulated microgravity. J Cell Biochem 2008;104:1324-1341.

10 Infanger M, Kossmehl P, Shakibaei M, Baatout S, Witzin A, Grosse J, Bauer J, Cogoli A, Faramarzi S, Derradji H, Neefs M, Paul M, Grimm D: Induction of three-dimensional assembly and increase in apoptosis of human endothelial cells by simulated microgravity: Impact of vascular endothelial growth factor. Apoptosis 2006;11:749-764.

11 Grosse J, Wehland M, Pietsch J, Ma X, Ulbrich C, Schulz H, Saar K, Hübner N, Hauslage J, Hemmersbach R, Braun M, van Loon J, Vagt N, Infanger M, Eilles C, Egli M, Richter P, Baltz T, Einspanier R, Sharbati S, Grimm D: Short-term weightlessness produced by parabolic flight maneuvers altered gene expression patterns in human endothelial cells. FASEB J 2012;26:639-655.

12 Grimm D, Infanger M, Westphal K, Ulbrich C, Pietsch J, Kossmehl P, Vadrucci S, Baatout S, Flick B, Paul M, Bauer J: A delayed type of three-dimensional growth of human endothelial cells under simulated weightlessness. Tissue Eng Part A 2009;15:2267-2275.

13 Grimm D, Bauer J, Ulbrich C, Westphal K, Wehland M, Infanger M, Aleshcheva G, Pietsch J, Gardi M, Beck M, El-Saghire H, de Saint-Georges L, Baatout S: Different responsiveness of endothelial cells to VEGF and bFGF added to culture media under gravity and simulated microgravity. Tissue Eng Part A 2010;16:1559-1573.

14 Grimm D, Wise P, Lebert M, Richter P, Baatout S: How and why does the proteome respond to microgravity? Expert Rev Proteomics 2011;8:13-27.

15 Pietsch J, Bauer J, Egli M, Infanger M, Wise P, Ulbrich C, Grimm D: The effects of weightlessness on the human organism and mammalian cells. Curr Mol Med 2011;11:350-364.

16 Buravkova LB, Romanov YA: The role of cytoskeleton in cell changes under condition of simulated microgravity. Acta Astronaut 2001;48:647-650.

17 Versari S, Villa A, Bradamante S, Maier J: Alterations of the actin cytoskeleton and increased nitric oxide synthesis are common features in human primary endothelial cell response to changes in gravity. Biochem Biophys Acta 2007;1773:1645-1652.

18 Carlsson SI, Bertilaccio MT, Ballabio E, Maier JA: Endothelial stress by gravitational unloading: effects on cell growth and cytoskeletal organization. Biochem Biophys Acta 2003;1642:173-179.

19 Cotrupi S, Ranzani D, Maier, JA: Impact of modeled microgravity on microvascular endothelial cells. Biochem Biophys Acta 2005;1746:163-168.

20 Siamwala JH, Reddy SH, Majumder S, Kolluru GK, Muley A, Sinha S, Chatterjee S: Simulated microgravity perturbs actin polymerization to promote nitric oxide-associated migration in human immortalized Eahy926 cells. Protoplasma 2010;242:3-12.

21 Sumanasekera WK, Zhao L, Ivanova M, Morgan DD, Noisin EL, Keynton RS, Klinge CM: Effect of estradiol and dihydrotestosterone on hypergravity-induced MAPK signaling and occludin expression in human umbilical vein endothelial cells. Cell Tissue Res 2006;324:243-253.

-22 Spisni E, Bianco MC, Blasi F, Santi S, Riccio M, Toni M, Griffoni C, Tomasi V: Hypergravity impairs angiogenic response of in vitro cultured human primary endothelial cells. J Gravit Physiol 2002;9:285-286.

23 Ito Y, Kimura T, Ago Y, Nam K, Hiraku K, Miyazaki K, Masuzawa T, Kishida A: Nano-vibration effect on cell adhesion and its shape. Biomed Mater Eng 2011;21:149-158.

24 White CR, Haidekker MA, Stevens HY, Frangos JA: Extracellular signal-regulated kinase activation and endothelin-1 production in human endothelial cells exposed to vibration. J Physiol 2004;55:565-572.

25 Edgell CJ, McDonald CC, Graham JB: Permanent cell line expressing human factor VIII-related antigen established by hybridization. Proc Natl Acad Sci USA 1983;80:3734-3737.

-26 Ulbrich C, Pietsch J, Grosse J, Wehland M, Schulz H, Saar K, Hübner N, Hauslage J, Hemmersbach R, Braun M, van Loon J, Vagt N, Egli M, Richter P, Einspanier R, Sharbati S, Baltz T, Infanger M, Ma X, Grimm D: Differential gene regulation under altered gravity conditions in follicular thyroid cancer cells: relationship between the extracellular matrix and the cytoskeleton. Cell Physiol Biochem 2011;28:185-198.

27 Schmidt W: Quickly changing acceleration forces (QCAFs) vibration analysis on the A300 ZERO-G. Microgravity Sci Technol 2004;15:42-48.

28 Kossmehl P, Schönberger J, Shakibaei M, Faramarzi S., Kurth E, Habighorst B, von Bauer R, Wehland M, Kreutz R, Infanger M, Schulze-Tanzil G, Paul M, Grimm D: Increase of fibronectin and osteopontin in porcine hearts following ischemia and reperfusion. J Mol Med 2005;83:626-637.

29 Riecke K, Grimm D, Shakibaei M, Kossmehl P, Schulze-Tanzil G, Paul M, Stahlmann R: Low doses of 2,3,7,8-tetrachlorodibenzo- p-dioxin increase transforming growth factor beta and cause myocardial fibrosis in marmosets (Callithrix jacchus). Arch Toxicol 2002;76:360-366.

30 Rothermund L, Kreutz R, Kossmehl P, Fredersdorf S, Shakibaei M, Schulze-Tanzil G, Paul M, Grimm D: Early onset of chondroitin sulfate and osteopontin expression in Angiotensin II-dependent left ventricular hypertrophy. Am J Hypertens 2002;15:644-652.

-31 Infanger M, Faramarzi S, Grosse J, Kurth E, Ulbrich C, Bauer J, Wehland M, Kreutz R, Kossmehl P, Paul M, Grimm D: Expression of vascular endothelial growth factor and receptor tyrosine kinases in cardiac ischemia/reperfusion injury. Cardiovasc Pathol 2007;16:291-299. 
Wehland et al.: Effects of Parabolic Flight Maneuvers on Endothelial Cells

32 Neisch AL, Fehon RG: Ezrin, Radixin and Moesin: key regulators of membrane-cortex interactions and signaling. Curr Opin Cell Biol 2011;23:377-382.

33 Fehon RG, McClatchey AI, Bretscher A: Organizing the cell cortex: the role of ERM proteins. Nat Rev Mol Cell Biol 2010;11:276-287.

34 Lankes WT, Furthmayr H: Moesin: a member of the protein 4.1-talin-ezrin family of proteins. Proc Natl Acad Sci USA 1991;88:8297-8301.

-35 Krieg J, Hunter T: Identification of the two major epidermal growth factor-induced tyrosine phosphorylation sites in the microvillar core protein ezrin. J Biol Chem 1992;267:19258-19265.

-36 Turunen 0, Wahlström T, Vaheri A: Ezrin has a COOH-terminal actin-binding site that is conserved in the ezrin protein family. J Cell Biol 1994;126:1445-1453.

-37 Mackay DJ, Esch F, Furthmayr H, Hall A: Rho- and rac-dependent assembly of focal adhesion complexes and actin filaments in permeabilized fibroblasts: an essential role for ezrin/radixin/moesin proteins. J Cell Biol 1997;138: 27-938.

38 Hirao M, Sato N, Kondo T, Yonemura S, Monden M, Sasaki T, Takai Y, Tsukita S, Tsukita S: Regulation mechanism of ERM (ezrin/radixin/moesin) protein/plasma membrane association: possible involvement of phosphatidylinositol turnover and Rho-dependent signaling pathway. J Cell Biol 1996;135:37-51.

39 Hatzoglou A, Ader I, Splingard A, Flanders J, Saade E, Leroy I, Traver S, Aresta S, de Gunzburg J: Gem associates with Ezrin and acts via the Rho-GAP protein Gmip to down-regulate the Rho pathway. Mol Biol Cell 2007;18:1242-1252.

40 D'Angelo R, Aresta S, Blangy A, Del Maestro L, Louvard D, Arpin M: Interaction of ezrin with the novel guanine nucleotide exchange factor PLEKHG6 promotes RhoG-dependent apical cytoskeleton rearrangements in epithelial cells. Mol Biol Cell 2007;18:4780-4793.

-41 Van Fürden D, Johnson K, Segbert C, Bossinger O: The C. elegans ezrin-radixin-moesin protein ERM-1 is necessary for apical junction remodelling and tubulogenesis in the intestine. Dev Biol 2004;272:262-276.

42 Kerman BE, Cheshire AM, Myat MM, Andrew DJ: Ribbon modulates apical membrane during tube elongation through Crumbs and Moesin. Dev Biol 2008;320:278-288.

43 Louvet S, Aghion J, Santa-Maria A, Mangeat P, Maro B: Ezrin becomes restricted to outer cells following asymmetrical division in the preimplantation mouse embryo. Dev Biol 1996;177:568-579.

$\checkmark 44$ Grimm D, Bauer J, Schoenberger J: Blockade of neoangiogenesis, a new and promising technique to control the growth of malignant tumors and their metastases. Curr Vasc Pharmacol 2009;7:347-357.

$\$ 45$ Ferrara N: Vascular endothelial growth factor: basic science and clinical progress. Endocr Rev 2004;25:581-611.

46 Leung DW, Cachianes G, Kuang WJ, Goeddel DV, Ferrara N: Vascular endothelial growth factor is a secreted angiogenic mitogen. Science 1989;246:1306-1309.

47 Infanger M, Shakibaei M, Kossmehl P, Hollenberg SM, Grosse J, Faramarzi S, Schulze-Tanzil G, Paul M, Grimm D: Intraluminal application of vascular endothelial growth factor enhances healing of microvascular anastomosis in a rat model. J Vasc Res 2005;42:202-213.

48 Infanger M, Schmidt O, Kossmehl P, Grad S, Ertel W, Grimm D: Vascular endothelial growth factor serum level is strongly enhanced after burn injury and correlated with local and general tissue edema. Burns 2004;30:305-311.

-49 Infanger M, Grosse J, Westphal K, Leder A, Ulbrich C, Paul M, Grimm D: Vascular endothelial growth factor induces extracellular matrix proteins and osteopontin in the umbilical artery. Ann Vasc Surg 2008;22:273284.

50 Alon T, Hemo I, Itin A, Pe'er J, Stone J, Keshet E: Vascular endothelial growth factor acts as a survival factor for newly formed retinal vessels and has implications for retinopathy of prematurity. Nat Med 1995;1:1024-1028.

51 Hynes RO: Integrins: bidirectional, allosteric signaling machines. Cell 2002;110:673-687.

52 Wang KX, Denhardt DT: Osteopontin: role in immune regulation and stress responses. Cytokine Growth Factor Rev 2008;19:333-345.

53 Laffón A, García-Vicuña R, Humbría A, Postigo AA, Corbí AL, de Landázuri MO, Sánchez-Madrid F: Upregulated expression and function of VLA-4 fibronectin receptors on human activated $\mathrm{T}$ cells in rheumatoid arthritis. J Clin Invest 1991;88:546-552.

54 Schoenberger J, Bauer J, Moosbauer J, Eilles C, Grimm D: Innovative strategies in in vivo apoptosis imaging. Curr Med Chem 2008;15:187-194.

-55 Denhardt DT, Noda M, O'Regan AW, Pavlin D, Berman JS: Osteopontin as a means to cope with environmental insults: regulation of inflammation, tissue remodeling, and cell survival. J Clin Invest 2001;107:1055-1061.

56 Standal T, Borset M, Sundan A: Role of osteopontin in adhesion, migration, cell survival and bone remodeling. Exp Oncol 2004;26:179-184.

57 Steller H: Mechanisms and genes of cellular suicide. Science 1995;267:1445-1449.

58 Orrenius S: Apoptosis: molecular mechanisms and implications for human disease. J Intern Med 1995;237:529-536. 
Wehland et al.: Effects of Parabolic Flight Maneuvers on Endothelial Cells

59 Ameisen JC: On the origin, evolution, and nature of programmed cell death: a timeline of four billion years. Cell Death Differ 2002;9:367-393.

60 Kossmehl P, Kurth E, Faramarzi S, Habighorst B, Shakibaei M, Wehland M, Kreutz R, Infanger M, J Danser AH, Grosse J, Paul M, Grimm D: Mechanisms of apoptosis after ischemia and reperfusion: role of the reninangiotensin system. Apoptosis 2006;11:347-358.

-61 Grimm D, Wehland M, Pietsch J, Infanger M, Bauer J: Drugs interfering with apoptosis in breast cancer. Curr Pharm Des 2011;17:272-283.

62 Fuentes-Prior P, Salvesen GS: The protein structures that shape caspase activity, specificity, activation and inhibition. Biochem J 2004;384:201-232.

63 Huerta S, Goulet EJ, Huerta-Yepez S, Livingston EH: Screening and detection of apoptosis. J Surg Res 2007;139:143-156.

64 Fischer U, Jänicke RU, Schulze-Osthoff K: Many cuts to ruin: a comprehensive update of caspase substrates. Cell Death Differ 2003;10:76-100.

65 Raynal P, Pollard HB: Annexins: the problem of assessing the biological role for a gene family of multifunctional calcium- and phospholipid-binding proteins. Biochem Biophys Acta 1994;1197:63-93.

-66 Draeger A, Wray S, Babiychuk EB: Domain architecture of the smooth-muscle plasma membrane: regulation by annexins. Biochem J 2005;387:309-314.

67 Raynal P, Hullin F, Ragab-Thomas JM, Fauvel J, Chap H: Annexin 5 as a potential regulator of annexin 1 phosphorylation by protein kinase C. In vitro inhibition compared with quantitative data on annexin distribution in human endothelial cells. Biochem J 1993;292:759-765.

68 Eberhard DA, Vandenberg SR: Annexins I and II bind to lipid A: a possible role in the inhibition of endotoxins. Biochem J 1998;330:67-72.

69 Mayran N, Parton RG, Gruenberg J: Annexin II regulates multivesicular endosome biogenesis in the degradation pathway of animal cells. EMBO J 2003;22:3242-3253.

70 Hayes MJ, Rescher U, Gerke V, Moss SE: Annexin-actin interactions. Traffic 2004;5:571-576.

-71 De BK, Misono KS, Lukas TJ, Mroczkowski B, Cohen S: A calcium-dependent 35-kilodalton substrate for epidermal growth factor receptor/kinase isolated from normal tissue. J Biol Chem 1986;261:13784-13792.

72 Croxtall JD, Waheed S, Choudhury Q, Anand R, Flower RJ: N-terminal peptide fragments of lipocortin-1 inhibit A549 cell growth and block EGF-induced stimulation of proliferation. Int J Cancer 1993;54:153-158.

73 Canaider S, Solito E, de Coupade C, Flower RJ, Russo-Marie F, Goulding NJ, Perretti M: Increased apoptosis in U937 cells over-expressing lipocortin 1 (annexin I). Life Sci 2000;66:265-270.

74 Solito E, de Coupade C, Canaider S, Goulding NJ, Perretti M: Transfection of annexin 1 in monocytic cells produces a high degree of spontaneous and stimulated apoptosis associated with caspase- 3 activation. $\mathrm{Br} \mathrm{J}$ Pharmacol 2001;133:217-228.

75 Solito E, Kamal A, Russo-Marie F, Buckingham JC, Marullo S, Perretti M: A novel calcium-dependent proapoptotic effect of annexin 1 on human neutrophils. FASEB J 2003;17:1544-1546.

76 Johnson ME, Howerth EW: Survivin: a bifunctional inhibitor of apoptosis protein. Vet Pathol 2004;41:599607.

-77 Cheung CH, Sun X, Kanwar JR, Bai JZ, Cheng L, Krissansen GW: A cell-permeable dominant-negative survivin protein induces apoptosis and sensitizes prostate cancer cells to TNF- $\alpha$ therapy. Cancer Cell Int 2010;10:36.

-78 Kanwar JR, Shen WP, Kanwar RK, Berg RW, Krissansen GW: Effects of survivin antagonists on growth of established tumors and B7-1 immunogene therapy. J Natl Cancer Inst 2001;93:1541-1552.

79 Shin S, Sung BJ, Cho YS, Kim HJ, Ha NC, Hwang JI, Chung CW, Jung YK, Oh BH: An anti-apoptotic protein human survivin is a direct inhibitor of caspase-3 and -7. Biochemistry 2001;40:1117-1113.

80 Liu T, Brouha B, Grossman D: Rapid induction of mitochondrial events and caspase-independent apoptosis in Survivin-targeted melanoma cells. Oncogene 2004;23:39-48.

81 Murray AW: Recycling the cell cycle: cyclins revisited. Cell 2004;116:221-234.

-82 Bloom J, Cross FR: Multiple levels of cyclin specificity in cell-cycle control. Nat Rev Mol Cell Biol 2007;8:149-160.

83 Ravnik SE, Wolgemuth DJ: The developmentally restricted pattern of expression in the male germ line of a murine cyclin A, cyclin A2, suggests roles in both mitotic and meiotic cell cycles. Dev Biol 1996;173:69-78.

84 Sweeney C, Murphy M, Kubelka M, Ravnik SE, Hawkins CF, Wolgemuth DJ, Carrington M: A distinct cyclin A is expressed in germ cells in the mouse. Development 1996;122:53-64.

85 Yang R, Morosetti R, Koeffler HP: Characterization of a second human cyclin A that is highly expressed in testis and in several leukemic cell lines. Cancer Res 1997;57:913-920.

-86 Pagano M, Pepperkok R, Verde F, Ansorge W, Draetta G: Cyclin A is required at two points in the human cell cycle. EMBO J 1992;11:9619-9671.

87 Yam CH, Fung TK, Poon RY: Cyclin A in cell cycle control and cancer. Cell Mol Life Sci 2002;59:1317-1326.

88 De Boer L, Oakes V, Beamish H, Giles N, Stevens F, Somodevilla-Torres M, Desouza C, Gabrielli B: Cyclin A/ cdk2 coordinates centrosomal and nuclear mitotic events. Oncogene 2008;27:4261-4268. 
Wehland et al.: Effects of Parabolic Flight Maneuvers on Endothelial Cells

89 Sherr CJ: G1 phase progression: cycling on cue. Cell 1994;79:551-555.

-90 Sicinski P, Donaher JL, Parker SB, Li T, Fazeli A, Gardner H, Haslam SZ, Bronson RT, Elledge SJ, Weinberg RA: Cyclin D1 provides a link between development and oncogenesis in the retina and breast. Cell 1995;82:621-630.

91 Freeman RS, Estus S, Johnson EM Jr: Analysis of cell cycle-related gene expression in postmitotic neurons: selective induction of Cyclin D1 during programmed cell death. Neuron 1994;12:343-355.

92 Zwijsen RM, Buckle RS, Hijmans EM, Loomans CJ, Bernards R: Ligand-independent recruitment of steroid receptor coactivators to estrogen receptor by cyclin D1. Genes Dev 1998;2:3488-3498.

-93 Sherr CJ, Roberts JM: Inhibitors of mammalian G1 cyclin-dependent kinases. Genes Dev 1995;9:11491163.

94 Sherr CJ, Roberts JM: CDK inhibitors: positive and negative regulators of G1-phase progression. Genes Dev 1999;13:1501-1512.

95 Xiong Y, Zhang H, Beach D: D type cyclins associate with multiple protein kinases and the DNA replication and repair factor PCNA. Cell 1992;71:505-514.

-96 Nakanishi M, Adami GR, Robetorye RS, Noda A, Venable SF, Dimitrov D, Pereira-Smith OM, Smith JR: Exit from G0 and entry into the cell cycle of cells expressing p21Sdi1 antisense RNA. Proc Natl Acad Sci USA 1995; 92:4352-4356.

-97 Li Y, Jenkins CW, Nichols MA, Xiong Y: Cell cycle expression and p53 regulation of the cyclin-dependent kinase inhibitor p21. Oncogene 1994;9:2261-2268.

-98 Zhang Y, Fujita N, Tsuruo T: Caspase-mediated cleavage of p21Waf1/Cip1 converts cancer cells from growth arrest to undergoing apoptosis. Oncogene 1999;18:1131-1138.

$\$ 99$ Jónsson ZO, Hübscher U: Proliferating cell nuclear antigen: more than a clamp for DNA polymerases. Bioessays 1997;19:967-975.

100 Noda A, Ning Y, Venable SF, Pereira-Smith OM, Smith JR: Cloning of senescent cell-derived inhibitors of DNA synthesis using an expression screen. Exp Cell Res 1994;211:90-98.

101 Thiel CS, Paulsen K, Bradacs G, Lust K, Tauber S, Dumrese C, Hilliger A, Schoppmann K, Biskup J, Gölz N, Sang C, Ziegler U, Grote KH, Zipp F, Zhuang F, Engelmann F, Hemmersbach R, Cogoli A, Ullrich O: Rapid alterations of cell cycle control proteins in human T lymphocytes in microgravity. Cell Commun Signal 2012;10:1.

102 Hateboer G, Wobst A, Petersen BO, Le Cam L, Vigo E, Sardet C, Helin K: Cell cycle-regulated expression of mammalian CDC6 is dependent on E2F. Mol Cell Biol 1998;18:6679-6697.

103 Yan Z, DeGregori J, Shohet R, Leone G, Stillman B, Nevins JR, Williams RS: Cdc6 is regulated by E2F and is essential for DNA replication in mammalian cells. Proc Natl Acad Sci USA 1998;95:3603-3608.

104 Feng D, Tu Z, Wu W, Liang C: Inhibiting the expression of DNA replication-initiation proteins induces apoptosis in human cancer cells. Cancer Res 2003;63:7356-7364.

105 Lau E, Zhu C, Abraham RT, Jiang W: The functional role of Cdc6 in S-G2/M in mammalian cells. EMBO Rep 2006;7:425-430.

106 Gillespie PG, Walker RG: Molecular basis of mechanosensory transduction. Nature 2001;413:194-202.

-107 Olesen SP, Clapham DE, Davies PF: Haemodynamic shear stress activates a K+ current in vascular endothelial cells. Nature 1988;331:168-170.

108 Kanzaki M, Nagasawa M, Kojima I, Sato C, Naruse K, Sokabe M, Iida H: Molecular identification of a eukaryotic, stretch-activated nonselective cation channel. Science 1999;285:882-886.

109 Tseng H, Peterson TE, Berk BC: Fluid shear stress stimulates mitogen-activated protein kinase in endothelial cells. Circ Res 1995;77:869-878.

110 Yamazaki T, Tobe K, Hoh E, Maemura K, Kaida T, Komuro I, Tamemoto H, Kadowaki T, Nagai R, Yazaki Y: Mechanical loading activates mitogen-activated protein kinase and S6 peptide kinase in cultured rat cardiac myocytes. J Biol Chem 1993;268:12069-12076.

111 Spisni E, Toni M, Strillacci A, Galleri G, Santi S, Griffoni C, Tomasi V: Caveolae and caveolae constituents in mechanosensing: effect of modeled microgravity on cultured human endothelial cells. Cell Biochem Biophys 2006;46:155-164.

112 Spisni E, Bianco MC, Griffoni C, Toni M, D'Angelo R, Santi S, Riccio M, Tomasi V: Mechanosensing role of caveolae and caveolar constituents in human endothelial cells. J Cell Physiol 2003;197:198-204.

113 Wang N, Butler JP, Ingber DE: Mechanotransduction across the cell surface and through the cytoskeleton. Science 1993;260:1124-1127.

114 Wang N, Ingber DE: Probing transmembrane mechanical coupling and cytomechanics using magnetic twisting cytometry. Biochem Cell Biol 1995;73:327-335

115 Tagawa H, Wang N, Narishige T, Ingber DE, Zile MR, Cooper G $4^{\text {th }}$ : Cytoskeletal mechanics in pressureoverload cardiac hypertrophy. Circ Res 1997;80:281-289.

116 Maniotis AJ, Chen CS, Ingber DE: Demonstration of mechanical connections between integrins, cytoskeletal filaments, and nucleoplasm that stabilize nuclear structure. Proc Natl Acad Sci USA 1997;94:849-854. 